\title{
Analysis of low level laser therapy in vitro cultures of bacteria and fungi
}

\section{Análise da terapia a laser de baixa intensidade em culturas in vitro de bactérias e fungo}

\author{
Rodrigo Antonio Carvalho Andraus', Luciana Prado Maia², João Paulo Manfré dos Santos', \\ Amanda Rezende Mesquita ${ }^{3}$, Thaynara Gonzaga Santos ${ }^{4}$, Alexandre Braoios ${ }^{4}$, Rodrigo Paschoal Prado ${ }^{3}$
}

\begin{abstract}
Background: Low intensity laser therapy has been used to accelerate the ulcers healing due to its healing, anti-inflammatory, analgesic and anti-edematous effects. Contaminations by bacteria or fungi on these ulcers commonly happen, constituting a major complication of healing, but there is no consensus about laser therapy bactericidal or fungicidal effect. Aim: To analyze the effects of different times of appliantion using the $808 \mathrm{~nm}$ and $660 \mathrm{~nm}$ lasers on cultures of different bacterial species and fungi in vitro. Method: Photon Lase III - DMC was used, with the wavelengths of 660 and $808 \mathrm{~nm}$ and $30 \mathrm{~mW}, 60 \mathrm{~mW}$ and $100 \mathrm{~mW}$ of power, with different exposure time to laser irradiation. Fifteen Petri plates were prepared, 12 plates containing Gram-positive (3 Staphylococcus aureus plates, 3 nterococcus plates) and gram negative bacterias (3 Escherichia coli, 3 Klebsiella pneumonia plates) and 3 Petri plates with the fungi Candida albicans. Plates were randomly divided into 3 groups with 5 plates each group. Plates of Group 1 were irradiated with $660 \mathrm{~nm}$ laser at nine different points $\left(A, A_{1}, A_{2} / B, B_{1}, B_{2} / C, C_{1}, C_{2}\right)$, and points $A / B / C$ reciebed only one application, points $A_{1}, B_{1}, C_{1}$ received 2 applications and points $A_{2}, B_{2}, C_{2}$ received 3 applications. Plates from group 2 where irradiated with $660 \mathrm{~nm}$ also in nine diferente points, following the same criterea of group 1, while plate of group 3 where used as control, without irradiation. Groups 1 and 2 were irradiated with $144 \mathrm{~J} / \mathrm{cm}^{2} \mathrm{dose}$ at point $A$ (irradiation time of 2 minutes and 15 seconds), point B (irradiation time of 1 minute 7 seconds) and at point C (40 seconds). After the irradiations the plates were incubated for 24 hours. The cultures were visually examined to check the presence or not of the inhibition zone. In all the groups, no zone of inhibition nor growth were observed. Conclusion: Low intensity laser therapy (808nm and $660 \mathrm{~nm}$ ) did not produce bactericidal and/or bacteriostatic effects, and even no bio-stimulant effect on the bacteria.
\end{abstract}

Keywords: Bacteria; Low intensity laser therapy; Infection; Fungi.

\section{RESUMO}

Introdução: A terapia a laser de baixa intensidade tem sido utilizada para acelerar a cicatrização das úlceras devido aos seus efeitos cicatrizantes, antiinflamatório, antiedematoso e analgésico. A contaminação bacteriana ou por fungos dessas úlceras é frequente constituindo-se numa importante complicação da cicatrização, mas não há consenso quanto a seu efeito bactericida ou fungicida. Objetivo: Analisar os efeitos de diferentes tempos de aplicação dos lasers 808nm e 660nm frente às culturas de diferentes espécies de bactérias e fungos in vitro. Método: Aparelho laser modelo Photon Lase III-DMC com comprimentos de onda 660 e $808 \mathrm{~nm}$ e diferentes potências: $30 \mathrm{~mW}, 60 \mathrm{~mW}$ e $100 \mathrm{~mW}$ com diferentes tempos de aplicação. Preparou-se 15 placas de Petri, sendo 12 placas com bactérias gram-positivas (3 placas Staphilococcus aureus, 3 placas Enterococo) e gram-negativas (3 placas Escherichia coli, 3 placas Klebsiella pneumoniae) e 3 placas de Petri com fungo Cândida albicans. Aleatoriamente dividiu-se as placas em 3 grupos, contendo 5 placas cada grupo. As placas do grupo 1 foram irradiados com o laser $808 \mathrm{~nm}$ em nove pontos diferentes $\left(A, A_{1}, A_{2} / B, B_{1}, B_{2} / C, C_{1}, C_{2}\right)$ onde os pontos $A / B / C$ receberam apenas 1 aplicação os pontos $A_{1}, B_{1}, C_{1}$ receberam 2 aplicações e os pontos $A_{2}, B_{2}, C_{2}$ receberam 3 aplicações. As placas do grupo 2 foram irradiados com o laser $660 \mathrm{~nm}$ também em nove pontos diferentes seguindo os mesmos critérios do grupo 1 , placas do grupo 3 foram usadas como controle, não recebendo irradiação. Os grupos 1 e 2 foram irradiados com densidade de energia de $144 \mathrm{~J} / \mathrm{cm}^{2}$, no ponto A (tempo de irradiação de 2 minutos e 15 segundos), no ponto B (tempo de irradiação de 1 minuto 7 segundos) e no ponto C (40 segundos). Ao final das aplicações as placas foram incubados por 24 horas. As culturas foram analisadas visualmente para verificação ou não do halo de inibição. Em todos os grupos não foi observado qualquer halo de inibição nem de crescimento. Conclusão: A terapia a laser de baixa intensidade $(808 \mathrm{~nm}$ e $660 \mathrm{~nm})$ não produziu efeito bactericidas e/ou bacteriostáticos e tampouco efeito bioestimulante sobre as bactérias.

Palavras-chave: Bactérias; Terapia a laser de baixa intensidade; Infecção; Fungos.

Corresponding Author: Phd Rodrigo Antonio Carvalho Andraus. Rua Marselha n. 591, Jardim Piza. Zip Code: $86041-140$ - Londrina, PR - Brazil. Phone: (43) 33717990. E-mail: rodrigoandraus@gmail.com

${ }^{1}$ North University of Parana, Rehabilitation Science Program, Londrina (PR), Brazil.

Full list of author information is available at the end of the article.

Financial Support: None.

Submission date 03 September 2014; Acceptance date 09 December 2014; Online publication date 17 December 2014 


\section{INTRODUCTION}

The increase in life expectancy of the world population increased up also chronic degenerative diseases, including chronic ulcers. In the field of physical therapy, countless individuals are sent every year to treat disabling trauma-orthopedic and neurological problems associated with injury to the skin, known as decubitus ulcers or pressure ulcers, resulting from a deficient blood supply caused by increased pressure by patient's own body weight on the bed in a specific region. ${ }^{(1)}$

However, a constant complication of chronic ulcers is secondary infection, where fungi and Gram-positive and Gram-negative bacteria, aerobic and anaerobic, can be usually find, attracting leukocytes, releasing enzymes, such as myeloperoxidase, and decreasing the amount of oxygen of the tissues, resulting in a temporary ischemia, which increases the risk of infection in addition of perpetuating the inflammatory process in the ulcers, not allowing its closure, as well as undermining the general state of the patient taking him, in extreme cases, to death. (2)

The physical therapist's role is to initially prevent the emergence of ulcers, particularly in hospital beds, doing joint mobilization of the patient or even making the change of decubitus in an interval of two hours, or at home, guiding the family. However, with ulceration frame in progress, the physical therapist uses some features such as cryo massage around the lesion, in an attempt to divert surface circulation deeper with the vasoconstrictor effect of ice. Another feature widely used by the physiotherapist in an attempt to speed up the healing of skin ulcers is low-intensity ultrasound. ${ }^{(3)}$

A widely used resource nowadays, as noninvasive modality, is the low level laser therapy. Many studies are done to assess the actual efficacy of low-level laser therapy in regard to the treatment of soft tissue injuries and the results have been satisfactory. Although several studies performed with low intensity laser therapy, especially in the light spectrum with visible wavelengths and infrared, little is known regarding the mechanisms of interaction with biological tissue and which photochemical and photothermal effects that this appeal may have on the tissues. ${ }^{(4)}$

In theory, their biomodularity capability of the skin healing process occur mainly during the proliferative phase, due to increased local cellular metabolism at the expense of mitochondrial upregulation. ${ }^{(5,6)}$ Research suggests that low-intensity laser increases cellular metabolism, stimulates oxidative phosphorylation and reduces the local inflammatory response, positively altering the electrophysiological properties of the irradiated tissue. ${ }^{(7)}$ In vitro keratinocyte cultures revealed that the low intensity laser stimulates the release of cytokines (IL-6 and IL- 8 ) and growth and differentiation factors (FGF - fibroblast growth factor) involved in skin repair process. ${ }^{(6)}$ The application of low intensity laser in the wound healing process seems interesting and promising.

It is postulated that the bactericidal effect of low level laser therapy (direct effect on bacterial membrane) occurs due to the absorption of photons by endogenous chromophores (inside the bacteria), with concurrent production of highly reactive and cytotoxic molecules, which cause disruption of membrane and bacterial killing. ${ }^{(8)}$ However, wound infection constitutes a barrier to the application of laser therapy, because it is believed that radiation can cause increased bacterial or fungal growth. ${ }^{(9)}$

Although some studies show the bactericidal and / or bacteriostatic laser effect, there is still the paradox of studies that have found increased bacterial growth (especially Escherichia coli) and there are few studies showing the fungicidal effect of the laser. ${ }^{(8,10)}$

The fact is that the increasing resistance of bacteria and fungi to the antifungal and antibiotic drugs makes it necessary to develop new bacteriostatics, bactericides and fungicides methods to cooperate with the treatment of infected individuals.

However, there are few studies that provide practical information on the fungicidal and bactericidal effect of low level laser therapy, there is no consensus on the results of these therapies in wound healing. The studies of the bactericidal effect of such therapies used different types of lasers with different wavelengths, power and irradiation doses, and no recommendation can be made regarding the type of laser and optimum wavelength for such therapy. ${ }^{(11)}$

Therefore, the aim of this study was to evaluate and compare the effectiveness of lasers $808 \mathrm{~nm}$ and $660 \mathrm{~nm}$ on growth inhibition in different species of bacteria (gram-positive and gram-negative) and fungi in vitro, using the same dose and in more than one laser application. Furthermore, it was verified the effectiveness of different times of exposure of cultures to low-level laser therapy, by using different powers.

\section{MATERIALS AND METHODS}

This study was developed in the Microbiology Laboratory of the Universidade Federal de Goiás (UFG). And since it was used bacteria and fungi created in the laboratory there was no need of approval from the Ethics Committee.

\section{Bacterial cultures}

Bacteria and fungi from the laboratory described in the literature as causes of infection in pressure ulcers, such as Escherichia coli (E. coli), Klebsiella pneumoniae (K. pneumoniae) (gram-negative bacteria) and Staphylococcus aureus (S. aureus), Enterococcus (gram-positive) and Candida albicans fungus were used

The sensitivity test laser was made using strains of E. coli, K. pneumoniae, S. aureus, Enterococcus and Candida albicans. 
Frozen stocks were heated slowly to reach room temperature and then inoculated with the aid of a platinum loop in $\mathrm{BHI}$ (Brain Heart Infusion Broth) for 24 hours at 36.5 ㅇ $\mathrm{C}$ and then plated on Nutrient Agar and incubated for 24 hours at $35 \circ \mathrm{C}$. After 24 hours a bacterial suspension in saline $0.5 \mathrm{McF}$ arland was performed. With the aid of a sterile swab, the sample was seeded in three directions in Mueller Hinton agar, subsequently the laser was applied and the plate was incubated at $37{ }^{\circ} \mathrm{C}$ for 24 hours.

\section{Laser radiation emitting equipment}

The equipment Model III Photon Lase DMC ${ }^{\circledR}$ mark was used, with the following parameters: Output power $30 \mathrm{~mW}$, $60 \mathrm{~mW}$ and $100 \mathrm{~mW}$, wavelength of $660 \mathrm{~nm}$ and $808 \mathrm{~nm}$, light beam of red color and infrared respectively, continuous emission, direct and without contact. The device was previously measured at the beginning of the work. The energy density used was $144 \mathrm{~J} / \mathrm{cm}^{2}$ (dose), total energy 4J.

\section{Procedure}

15 Petri dishes were prepared with AMH culture medium, where the bacteria Escherichia coli were seeded, Klebsiella pneumoniae (Gram negative bacteria), Staphylococcus aureus, Enterococcus (gram-positive) and the fungus Candida albicans were cultivated from standard strains.

The plates of bacteria and fungi were randomly divided into 3 groups, with five plates of each bacteria and fungus in each group.

Each plate received a labeling of each point to be irradiated, divided into the 3 lines were where the microorganisms where cultivated (Figure 1). The laser was irradiated only once at points A, B and C. At points A1, B1, C1 laser was applied 2 times with 15 minutes time intervals between each application. At points A2, B2, C2 laser was applied 3 times with a 15 minutes time intervals between each application.

The plates of group 1 were irradiated with $808 \mathrm{~nm}$ laser at nine different points ( $A, A 1, A 2$ / B, B1, B2, / C, C1, C2), following the label already described. At group 2, plates were irradiated with 660nm laser at nine different points ( $A, A 1, A 2$ / B, B1, B2, / C, C1, C2), following the same criteria of group 1 . The plates of group 3 were used as control, being subjected to the irradiation procedures, but with the laser unit off (sham).

Groups 2 and 3 were irradiated with energy density of $144 \mathrm{~J} / \mathrm{cm}^{2}$, a total energy of $4 \mathrm{~J}$, continuous beam and different potencies. The irradiation periods were established taking into account the desired dose, the area to be irradiated, and the laser power, and at points A, A1 and A2 on each plate it was used $30 \mathrm{~mW}$ of power (2 minutes irradiation time and 15 seconds); $60 \mathrm{~mW}$ of power at points $\mathrm{B}, \mathrm{B} 1$ and $\mathrm{B} 2$ (irradiation time of 1 minute 7 seconds) and $100 \mathrm{~mW}$ of power at points $C$, C1 and C2 (40 seconds).
The irradiation of laser was made by spot technique without contact, with a distance between the laser and the irradiation area at the culture plate of $1 \mathrm{~cm}$, distance standardized and kept by the laser holder (Figure 2).

After sham or laser irradiation, plates were incubated for 24 hours in aerobic oven with a maximum temperature measured at $37^{\circ} \mathrm{C}$. After incubation, the area of inhibition of bacterial growth was measured with the aid of a specially prepared template (sheet of graph paper). The results were evaluated by the presence of an inhibition zone. The inhibition zones were interpreted as resistant, intermediate or sensitive. All samples were handled in contamination-free area (laminar flow and Bunsen burner).

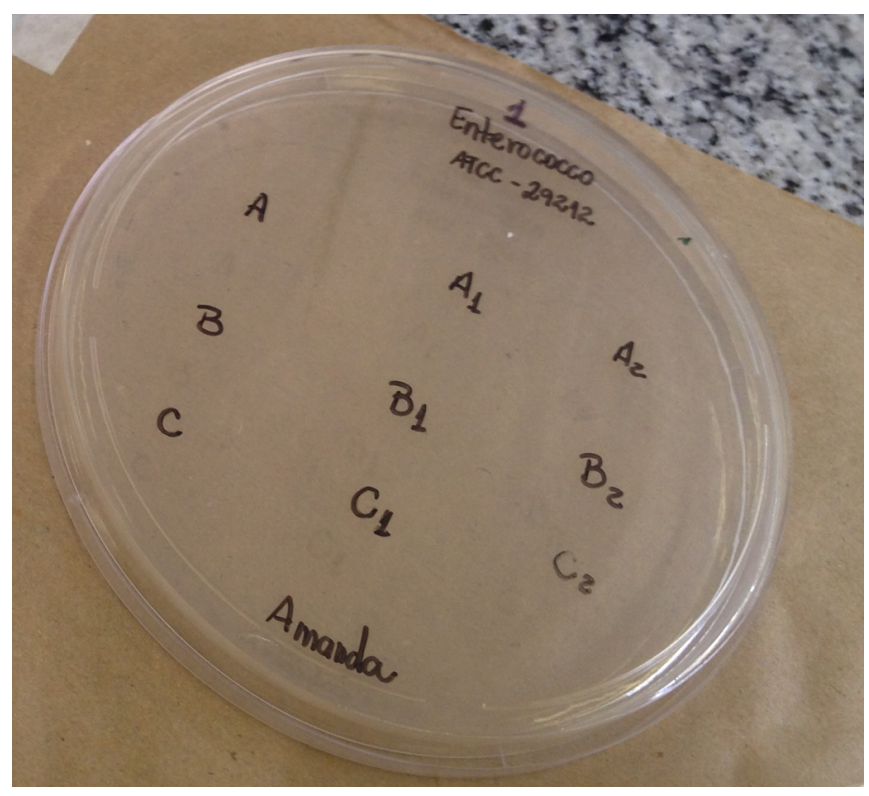

Figure 1. Marks on the boards of irradiation points.

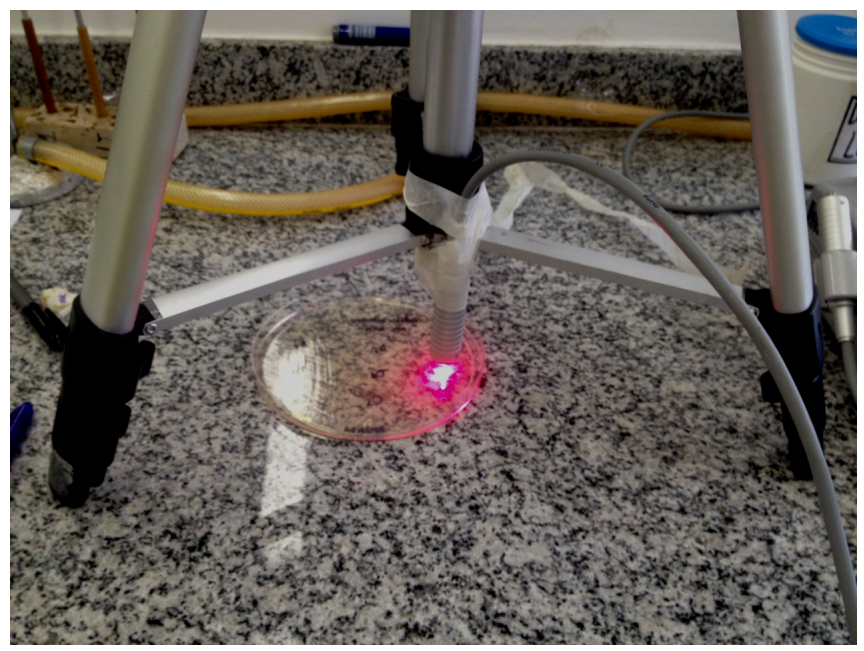

Figure 2. Illustration of the use of laser radiation on the cultivated Petri dish. 


\section{RESULTS}

For all groups and subgroups (exposure time) analyzed with irradiation of $660 \mathrm{~nm}$ or $808 \mathrm{~nm}$ and control group, on bacteria and fungus, it was not observed any inhibition halos and/or growth in the irradiated areas, indicating no bactericidal/fungicidal and/or bactericidal effect, in other words, in all groups and locations with different time exposures (A - $30 \mathrm{~mW}, \mathrm{~B}$ - and C $60 \mathrm{~mW}-100 \mathrm{~mW}$ ) the growth of bacteria and fungi were equal.

\section{DISCUSSION}

The importance of low-level laser has been gaining considerable recognition in the last decade. Their possible clinical applications such as therapeutic modality in injuries of soft and hard tissue have been widely studied. ${ }^{(12)}$ Can be mentioned as therapeutic low intensity laser effects the proliferative effect, which increases the neo-angiogenesis, fibroblasts synthesis collagen and ATP (adenosine triphosphate); fibrinolytic effect, which facilitates fibrinolysis; anti-edematogenic effect, which facilitates venous-lymphatic return, due to vasodilation of the capillaries; anti-inflammatory effect that interferes with the synthesis of prostaglandins; analgesic effect, releasing chemotactic substances that stimulate the release of endorphins; and a possible fungicidal and bactericidal effect, by increasing the amount of interferon and by direct effect on fungal and bacterial membrane. ${ }^{(12)}$

Studies that show the bactericidal or bacteriostatic effect of laser radiation report that the radiation absorbed by chromophores may cause conformational changes in certain molecules, generating free radicals and reactive oxygen which, in turn, promote the disruption of bacterial membranes and fungi. ${ }^{(9,13)}$ Other research on the laser radiation effect on bacteria and fungi point to biostimulants or proliferative results, postulating that these effects are linked to changes generated by increased energy intake provided by the radiation in the respiratory chain of bactéria. ${ }^{(10,14)}$

However, the exact biophysical mechanisms of radiation of low intensity laser on bacterial and fungal cells have been poorly investigated, making controversial the use in suspected contamination or confirmed cases of injury to soft tissue. ${ }^{(15,16)}$ Moreover, Nussbaum et al. ${ }^{(15)}$ and Tiphlova, Karu ${ }^{(17)}$ proposed that the photobiological response of an organism to exposure to monochromatic light depends directly on irradiation parameters (wavelength, intensity and dose) and culture conditions germ. Thus, further research is needed to assess the actual effects of low level laser therapy in bacteria and fungi and the most effective parameters for safer clinical application.

For this study the bacteria and fungus were selected because of higher prevalence in hospital and more frequent infections in pressure ulcers. ${ }^{(11,18,19)}$ The choice of the in vitro method was based on previous studies in the literature that performed several experiments assessing the effects of laser on different types of bacteria using changes in wavelength, dosage and frequency. ${ }^{(6,15,20,21)}$

The growing method and evaluation of repeated cultures were described by Benvindo et al. ${ }^{(11)}$ and was choosed because its a good method for the development of bacteria and fungus in question, quick and easy to perform, and it is a wide domain of technical staff of the Microbiology Laboratory at the Goias Federal University (UFG) where the research was conducted.

The literature suggests that stimulation of the bacterial growth is significantly increased by repeated irradiation, compared to a single exposure. Laser treatments are generally applied to wounds three to five times a week, and, consequently, in infected wounds, the cumulative effects of the treatment should be considered. Most studies realized the irradiation of the dish in a single session and the count of the bacterial colonies were made after 24 hours. ${ }^{(6,15,20,21)}$ Thus, this study adopted two different irradiation times and more than one laser application, the evaluation being performed also after 24 hours to allow comparison of results.

A study by Libarone ${ }^{(22)}$ concluded that the use of low-level laser therapy was shown to have an inhibitory effect on the growth rate of $S$. aureus and $P$. aeruginosa in vitro using a dose of $4 \mathrm{~J}$ (energy density 133, 33J/cm2). Based on this successful outcome, the dose of $4 \mathrm{~J}$ (total energy) was adopted in this study, but the energy density was $144 \mathrm{~J} / \mathrm{cm} 2$ due to the specifications of the model used equipment.

One goal of this study was to evaluate and compare the efficacy of two different types of waves of laser lengths, one not visible $(808 \mathrm{~nm})$ and the other in the visible range $(660 \mathrm{~nm})$ in in vitro cultures of bacteria and fungus using the same dose.

Thus, the results of this study shows that the treated groups showed no zone of inhibition of bacterial growth, indicating that there is no bactericidal, bacteriostatic or fungicide effect of the lase used with the parameters in question. On the other hand, there was no increased bacterial and fungus growth in the treated groups compared to the control group, as both grew in the same way. This indicates that the laser radiation at the dose used, with the wavelengths of 808 and $660 \mathrm{~nm}$, caused no biostimulating effect on bacteria and fungi. Some studies in the literature corroborates with the results of our study, even if they have used different wavelengths and doses, as in the study of Benvindo et al. ${ }^{(11)}$, who investigate the bactericidal effect of laser therapy of low intensity and photodynamic therapy (PDT) with low-power laser, InGaP, $670 \mathrm{~nm}$, at doses of 2, 4 and $6 \mathrm{~J} / \mathrm{cm} 2$, in gram-positive and gram-negative bacteria in vitro. The authors concluded that low level laser therapy and photodynamic therapy (InGaP, $670 \mathrm{~nm}$ ) did not porduce bactericidal or bacteriostatic effects, not even a biostimulant effect over the bacteria was observed.

Costa ${ }^{(23)}$ using the low power laser, AsGa, $904 \mathrm{~nm}$, at a dosage $6 \mathrm{~J} / \mathrm{cm} 2$ in Pseudomonas aeruginosa and Staphylococcus aureus observed no growth inhibition halo on 
the plates and concluded that laser therapy (AsGa, $904 \mathrm{~nm}$, $6 \mathrm{~J} / \mathrm{cm}^{2}$ ) produced no bactericidal effect.

Pereira et al. ${ }^{(6)}$, which compared the effects of low level laser therapy in bacterial growth in vitro and in infected wounds in vivo using the laser gallium arsenide with a wavelength of $904 \mathrm{~nm}$ (infrared electromagnetic spectrum), with a dose of $3 \mathrm{~J} / \mathrm{cm}^{2}$, showed no change in bacterial growth of $S$. aureus at in vitro experiment groups and control, while in vivo they demonstrated a significant increase in the deposition of collagen type I and III in the scar in animal groups infected and irradiated.

Other research recently published by Chung et al $\left.\right|^{(16)}$ evaluated the effect of laser in various dosages and wavelengths (red - 630nm, infrared - 904nm, green - 525nm, blue - 465nm and UV - 350nm) in bacterial growth (Staphylococcus aureus, Escherichia coli and Pseudomonas aeruginosa). The authors concluded that the laser showed no inhibitory effect on the growth of these bacteria, confirming also the present study.

However, several studies have shown some positive results, as the study Nussbaum et al., ${ }^{(15)}$ which, by radiating with $660 \mathrm{~nm}$ P. aeruginosa, E. coli and S. aureus, observed marginal effects on bacterial growth $(p=0.07)$, with a general trend of decreasing growth. However, at other wavelengths (630 and $810 \mathrm{~nm}$ ) it was observed an overall increase in growth; and only at $905 \mathrm{~nm}$ the growth was not significant. The authors also reported that for Staphylococcus aureus no general effect on growth was observed.

Oh the other hand, the study of Souza et al. ${ }^{(24)}$ aimed to analyze bacterial morphology by atomic force microscopy (AFM), after the application of low intensity laser therapy at in vitro culture of Staphylococcus aureus and concluded that the laser reduced the growth of $S$. aureus with the wavelengths of 830 and $904 \mathrm{~nm}$, particularly with $904 \mathrm{~nm}$ and a fluence of $3 \mathrm{~J} / \mathrm{cm}^{2}$, where the larger topographical changes of the cell structure occurred.

Regarding the Candida albicans fungus, our study did not show positive results, but a study conducted by Maver-Biscanin et al. ${ }^{(25)}$ that aimed to evaluate the in vivo effect of irradiation with diode laser in fungus growth (Candida albicans) on both palatal mucosa and denture base materialsof patents who use prostheses. The authors concluded that the light of a low intensity laser can be valuable in treating fungi. The difference may be the favored conditions for being in vivo.

Another objective of this study was to assess the effectiveness of different exposure times (irradiation) of the cultures to the low-intensity laser therapy, through the use of different powers. All plates were irradiated at nine different points, with different powers (points $A-30 \mathrm{~mW} B-60 \mathrm{~mW}$ and $C-100 \mathrm{~mW})$ and application time $(A / B / C$ - received a single application $A 1 / B 1 / C 1$ - received two applications and A2/B2/C2 - received 3 applications). However, the results did not show growth inhibition zone and did not cause bio-stimulant effect on bacteria and fungus.

The only study in the literature that also analyzed different exposure times was performed by Coutinho et al. ${ }^{(14)}$ where lasers with $15 \mathrm{~W} / 904 \mathrm{~nm}$ for 200 seconds, and 20W/904nm for 230 seconds were used in Escherichia coli, Haemophilus influenzae, Klebsiella pneumoniae, Pseudomonas aeruginosa, Salmonella $s p$, Serratia $s p$ and Staphylococcus aureus and it was concluded that in the studied conditions the laser proved to be innocuous regarding the increase in the number of units forming bacterial colonies, at the doses used in this study, indicating that it can be used as an adjuvant in the process wound healing, even in the presence of contamination by bacteria evaluated, confirming the results of this study.

Although the results of this work have not confirmed bactericidal and/or bacteriostatic or fungicides effects of low level laser therapy, it is emphasized that this is an in vitro study and thus more research is necessary to confirm our findings, including in vivo studies. However, there is a very significant clinical importance since it was not observed that the wavelengths used in this study produced any change in the growth of bacteria and fungus.

\section{CONCLUSION}

On plates with Staphilococcus aureus, Enterococos, Escherichia coli, Klebsiella pneumoniae and Cândida albicans, nor low-intensity laser irradiation (660 and $808 \mathrm{~nm}$ ), nor the different exposure times produced any change in growth or inhibition of bacteria and fungus.

\section{ACKNOWLEGEMENTS}

We appreciate the willingness and cooperation of the staff (teachers and students) Microbiology Laboratory of the Federal University of Goiás - Regional Jataí (UFG), is fundamental for this research.

\section{AUTHORS CONTRIBUTION}

RACA: elaboration of the article, JPMS: elaboration of the article, LPM: elaboration of the article, ARM: data collection and search for articles to manuscript, TGS: data collection and search for articles to manuscript, $A B$ : orientation and elaboration, RPP: orientation and elaboration.

\section{COMPETING INTERESTS}

The authors declare no conflicts of interest.

\section{AUTHOR DETAILS}

${ }^{2}$ North University of Parana, Dental School, Londrina (PR), Brazil. ${ }^{3}$ Goias Federal University, Physiotherapy School, Jatai (GO), Brazil. ${ }^{4}$ Goias Federal University, Biomedicine School, Jatai (GO), Brazil.

\section{REFERENCES}

1. Diegelman RF, Evans MC. Wound Healing: An Overviewof Acute, Fibrotic and Delayed Healing. Frontiers in Biosciences. 2004; 9: 283-89. 
2. Mustoe TA, Cooter R, et al. International clinical guidelines for scar management. Plast Reconstr Surg. 2002;110: 560-72

3. Mendonça AC, Ferreira AS, Barbieri CH, Thomazine JA, Mazzer N. Efeitos do Ultra-som pulsado de baixa intensidade sobre a cicatrização por segunda intenção de lesões cutâneas totais em ratos. Acta Ortopédica Brasileira. 2006; 14: 152-57.

4. Posten W, Wrone A. Low-Level Laser Therapy for Wound Healing: Mechanism and Efficacy. Dermatologyc Surgery Inc. 2005; 31:334-340.

5. Medrado AP, Pugliese LS, Reis SR, Andrade ZA. Influence of low level laser therapy on wound healing and its biological action upon myofibroblasts. Laser in Surgery and Medicine. 2003; 32: 239-44.

6. Pereira PR, De Paula JB, Cielinski J, Pilonetto M, Von Bahten LC. Efeitos do laser de baixa intensidade em cultura bacteriana in vitro e ferida infectada in vivo. Rev. Col. Bras. Cir. 2014; 41(1): 049-055.

7. Reedy GK. Comparison of the photostimulatory effects of visible He-Ne and infared Gad-As lasers on healing impaired diabetic rat wounds. Laser in Surgery and Medicine. 2003; 33: 344-51

8. Karu T. Primary and secundar mechanism of action of visible to near-IR radiation cells. In: Journal Photochemical amd Photobiology. 1999; 49: 1-17.

9. Baxter D. Laserterapia de baixa intensidade. In: Kitchen S, editora. Eletroterapia: prática baseada em evidências. 11 ed. São Paulo: Manole; 2003. 171-90.

10. Kawamoto K, Senda N, Shimada K, Itol K, Hirano Y, Murai S. Antibacterial effect of yellow He-Ne laser irradiation with crystal violet solution on Porphyromonas gingivalis: an evaluation using experimental rat model involving subcutaneous abscess. Lasers Med Sci. 2000; 15:257-62.

11. Benvindo RG, Braun G, Carvalho AR, Bertolini GRF. Efeitos da terapia fotodinâmica e de uma única aplicação de laser de baixa potência em bactérias in vitro. Fisioter. Pesqui. 2008; 15(1): 53-57.

12. Lucas C, Criens-Poublon LJ, Cockrell CT, De Haan RJ. Wound healing in cell studies and animal model experiments by Low Level Laser Therapy; were clinical studies justified? A systematic review. Lasers Med Sci. 2002; 17(2):110-34.

13. Christiansen C, Desimone NA. Bactericidal Efect of 0.95-mW HeliumNeon and 5- $\mathrm{mW}$ Indium-Galium-Aluminum-Phosphate Laser Iradiation at Exposure Times of 30,60, and 120 Seconds on Photosensitzed Staphylococus aureus and Pseudomonas aeruginosa InVitro. Physical Therapy. 1999; 79:839-846.
14. Coutinho F, Giordano V, Santos CM, Carneiro AF, Amaral NP, Touma MC, Giordano M. O efeito do laser de baixa energia no crescimento bacteriano "in vitro". Rev Bras Ortop. 2007; 42(8):248-53.

15. Nussbaum EL, Lilge L, Mazzulli T. Effects of 630-, 660-, 810-, and 905-nm laser irradiation delivering radiant exposure of $1-50 \mathrm{~J} / \mathrm{cm} 2$ on three species of bacteria in vitro. J Clin Laser Med Surg. 2002; 20(6):325-33.

16. Chung AW, Petrofsky JS, Laymon M, Logoluso J, Park J, Lee J, Lee H. The effects of low level laser radiation on bacterial growth. Phys Ther Rehabil Sci. 2014; 3(1), 20-26.

17. Tiphlova O, Karu T. Action of low-intensity laser radiation on Escherichia coli. Crit Rev Biomed Eng. 1991; 18(6):387-412.

18. Thom KA, Schweizer ML, Osih RB, McGregor JC, Furuno JP, Perencevich EN, Harris AD. Impact of Empiric Antimicrobial Therapy on Outcomes in Patients with Escherichia coli and Klebsiella pneumoniae Bacteremia: A Cohort Study. BMC Infectious Diseases. 2008; 8:116.

19. Rodríguez CH, García $S$, Barberis $C$, Saposnik E, Weyland B, Nastro M, Losada A, Perazzi B, Almuzara M, Foccoli M, Vay C, Famiglietti A. Enterococcus spp.: Resistencia antimicrobiana en infecciones intrahospitalarias. Acta Bioquím Clín Latinoam, 2013; 47 (1):155-60.

20. Nussbaum EL, Lilge L, Mazzulli T. Effects of low-level laser therapy (LLLT) of $810 \mathrm{~nm}$ upon in vitro growth of bacteria: relevance of irradiance and radiant exposure. J Clin Laser Med Surg. 2003; 21(5):283-90.

21. Bisht D, Gupta SC, Misra V, Mital VP, Sharma P. Effect of low intensity laser radiation on healing of open skin wounds in rats. Indian J Med Res. 1994; 100:43-6.

22. Libanore DZ. Efeitos da terapia a laser de baixa intensidade (685 e 830nm) na taxa de proliferação bacteriana e na cicatrização de feridas cutâneas em modelo animal. Dissertação de Mestrado. Universidade de São Paulo - São Carlos, 2008.

23. Costa AF, Assis JCL. In vitro assessment of the bactericidal effect of lowpower arsenium-gallium (AsGa) laser treatment. An Bras Dermatol. 2012; 87(4):654-6.

24. Sousa NTA, Guirro RRJ, Santana HF, Ssilva CCM. In Vitro Analysis of Bacterial Morphology by Atomic Force Microscopy of Low Level Laser Therapy 660, 830 and $904 \mathrm{~nm}$. Photomedicine and Laser Surgery. 2012; May, 30(5): 281-285.

25. Maver-Biscanin M, Mravak-Stipetic M, Jerolimov V, Biscanin, A. Fungicidal Effect of Diode Laser Irradiation in Patients With Denture Stomatitis. Lasers in Surgery and Medicine. 2004; 35:259-262. 